\title{
A time to heal
}

\section{The health service needs balm not further bloodshed}

The NHS has become a battlefield on which everyone looks like losing - patients, staff, and government. What is needed now is a cease fire. With a new prime minister comes a glimmer of hope. No one who has survived the recent conflict and confusion in the NHS wants to repeat the experience. Yet if the government's reforms are pushed through at the promised pace there seems little alternative. How did things get to such a pass?

It all began, familiarly enough, with massive bed closures because health authorities were running out of money. Some very sick children died very public deaths, and concerned presidents of royal colleges visited Downing Street. The Prime Minister announced a review of the NHS. Hasty, shrouded in secrecy, reliant on those deemed "one of us," and kept from parliament until the last possible moment, it now seems all too typical of its time. The white paper that emerged a year later was long on principle but short on detail. No matter, the then Secretary of State for Health, Kenneth Clarke, delighted in filling in the gaps, often appearing to make things up as he went along. Almost as an afterthought most of Sir Roy Griffiths's recommendations for community care were tacked on to the reform bill, only to be shelved for two years within days of the bill becoming law because the government took fright at the cost.

Three years after the events precipitating the review hospitals are once again closing beds by the thousand as they try to wipe out their debts before the health reforms come into force next April.' Waiting lists for hospital admission have climbed to their highest level since March $1979 .{ }^{2}$ Managers have now been set the task of reducing waiting lists while clearing their health authorities' debts. Not surprisingly, the resignations have begun.

What hope have the new reforms of working? Given their dependence on the kind of information that the NHS has not routinely collected (such as the costs of individual procedures) and the absence of any accounting system that would allow money to follow the patient, the short answer is none. These crucial deficiencies could be made good-but not by April. Competition is meant to make the wheels of the new system go round; the only competition likely for the next few years is between self governing trusts and directly managed units over a limited capital budget and between fundholding general practices and the rest over a limited general practitioner budget. Meanwhile, there is the unhappy spectacle of doctors who may have trained for 20 years to become skilled at jobs they enjoy trying to turn themselves into managers overnight.

What should be done? Jettisoning the reforms outright would be wrong as some of their principles are sound. What is needed are better ways and more time to put these principles into practice. Meanwhile, medical audit and the resource management initiative - both begun before the NHS review - should certainly be extended. The "level playing field," with all health authorities beginning next year out of debt, should be pursued. (Some of the extra $£ 5$ bn that the BMA calculates the NHS needs could take care of this.) A waiting list approaching one million is scandalous; no more hospital beds should be closed to save money. The wages of the lowest paid health workers need to be substantially increased or the industrial action that they are understandably threatening will paralyse the service.

The NHS Management Executive has apparently conducted several small scale trials of the new reforms-with, according to some reports, far from reassuring results. Now the reforms should be piloted properly. Why not test them in a single region? South Western Region would be a likely candidate-it has been running an internal market since April, ${ }^{+}$and self governing applicants already account for one third of the region's beds. ${ }^{5}$ Any improvements should be compared with those of a region that has maintained the status quo (and received the same proportional increase in funding as the pilot region). Even if the experiment succeeds there are bound to be snags that would be cheaper to iron out in one region than nationally. If it fails then billions of pounds might be saved. Avoiding waste of this magnitude should matter to a country in deepening recession.

\section{Society has been wounded too}

Not only has the health service been wounded over the past decade: so has society. Over that time the gap between rich and poor has widened. Not everyone has benefited financially since 1979 despite claims to the contrary. ${ }^{6}$ (Those with incomes in the lowest $10 \%$ have suffered most, experiencing a fall of $5.7 \%$ in the real value of their incomes between 1979 and $1987 . .^{7}$ ) If there is time for farsightedness this side of the next election then the government could dust down the Black report and begin to act on the association between poverty and ill health. ${ }^{8}$ If not, then we will reap a toll of potentially avoidable illness in the future. 
Doctors and patients have not always recognised an identity of interests: a shared opposition to the government's reforms has thrown them together. The distance now separating the government from doctors and patients is in no one's interests - least of all the government's. The wider it gets the more difficult it will be to bridge, although bridge it the government must. Much depends on the Secretary of State for Health. It is too early to say whether the present incumbentthe fourth in 42 months - is suited to the job. (Nor, as we go to press, is it clear whether he will remain in the job.) In his favour are a natural caution and a belief, expressed in a newspaper article he wrote in 1986, that the government should ease up on institutions it had "shaken and uprooted." "What is the point of unending guerilla warfare against these institutions?" he wrote. "To abolish is a policy; to reform is a policy; to support is a policy; to wound is not."

All sides have been wounded now, although none of the wounds have proved fatal. Given time they could still heal. No irrevocable decisions have yet been taken; nor should they be. With a lull in the fighting people could do what they usually do in these circumstances: they sit down and talk. Fortunately, there is still time.

Senior assistant editor,

TONY DELAMO'THE $B M \mathcal{F}$

I Timmins N, O'Sullivan J, Jones J, Goodwin S, Ward S. NHS cuts 4,500 beds to save cash Independent 1990 Nov 7:1 (cols 2-8)

Delamothe $T$. Waiting lists up again. BMF 1990;301:1011.

Brindle 1). Health chief quits over $\mathrm{f} 1 \cdot 6 \mathrm{~m}$ cuts. Guardian 1990 Nov 17:6 (cols $7-8$.

Millar B. Emerging from the golden chrysalis. Health Service fournal 1990;100:1720-1.

Newchurch and Company. Newchurch guide to NHS trust applications. London: Newchurch, 1990:7 6 Thatcher M. Motion of no confidence in Her Majesty's Government. House of Commons Official Record (Hansard) 1990 Nov 22;181:col 448. (No 12.)

Department of Social Security. Households below aterage income. A statistical analysis 1981-1987. London: Government Statistical Service, 1990:52.

Black D, Morris JN, Smith C, Townsend P. Inequalities in health: the Black report. Harmondsworth: Penguin, 1982. (First published by the DHSS, 1980. New introduction by P Townsend and $\mathrm{N}$ Davidson.)

9 Waldegrave W. Now the warrior Thatcher must win the peace. Sunday Telegraph $19860 \mathrm{C1} 5$.

\section{Vitamin A and measles in Third World children}

\section{Supplements could be part of routine primary care}

Each year measles causes the deaths of about $1 \cdot 5$ million children and accounts for half of the deaths in developing countries that could be prevented by vaccines. ${ }^{1}$ Many more have the complications of measles-pneumonia, ${ }^{2}$ diarrhoea and malnutrition, ${ }^{3}$ and blindness. ${ }^{+}$The severity of measles seems to be related to nutritional state and intensity of exposure. Malnourished children have a higher mortality ${ }^{5}$ and more severe complications, ${ }^{6}$ as do those living in overcrowded accommodation. ${ }^{7}$ Yet evidence has existed for some time that vitamin A supplements are a cheap and effective way of preventing death and complications in children with measles, ${ }^{8}$ and a recent report has reinforced this message. ${ }^{9}$

That vitamins may protect against measles was first suggested by Ellison in $1932 . .^{8}$ Among British children with measles the group who received vitamin $A$ and D supplements had half the number of deaths as did the control group. Surprisingly, no further report on vitamins and measles was published until 1987, when Barclay et al observed that vitamin A reduced mortality from measles in a randomised clinical trial in Tanzania..$^{5}$ Although, again, children in the group receiving large doses of vitamin $A$ had half the number of deaths (six of 88) as did the control group (12 of 92), the results were not significant. Vitamin A was, however, significantly protective in children aged under 2 and in those whose measles was complicated by croup or laryngotracheobronchitis.

Further evidence that vitamin A has a protective effect in children with severe measles has now come from South Africa. ${ }^{9}$ Hussey and Klein conducted a randomised, double blind trial on 189 children with severe measles. They found that children given vitamin A (400000 IU) recovered more rapidly from pneumonia and diarrhoea, had a lower incidence of croup, and spent fewer days in hospital than did the group receiving placebo. Of the 12 children who died, 10 had received placebo.

The benefits of vitamin A in measles in African children may be explained by the low serum concentrations of vitamin A $(<0.7 \mu \mathrm{mol} / \mathrm{l})$ found in over $90 \%$ of children in the Tanzanian and South African studies. Clinically apparent vitamin A deficiency - for example, xerophthalmia -was, however, rare in both studies. Children with severe measles in Zaire have also been reported to have low serum vitamin A concentrations. ${ }^{10}$ Hussey and Klein suggest that inadequate mobilisation of hepatic stores may explain the low concentrations. ${ }^{9}$ In contrast, measles is an important factor in the development of vitamin A deficiency and xerophthalmia in Asia, especially Indonesia, where a high proportion of blindness due to corneal destruction is associated with measles. ${ }^{112}$ Among children in whom they were measured, serum vitamin A concentrations were found to be extremely low in those with active corneal disease and measles.

The measles virus infects and damages epithelial tissues throughout the body. Serum vitamin A concentrations in well nourished children with measles have been reported to be lower than those in malnourished children without measles, ${ }^{13}$ suggesting increased use of the vitamin during the infection.

Whatever the mechanism of vitamin A depletion in measles, there is now adequate evidence that vitamin A supplementation is beneficial, particularly in those at greatest risk of severe and life threatening complications-young children in developing countries. In 1987 the World Health Organisation recommended that high dose vitamin A supplementation should be provided for all children diagnosed as having measles in countries where the fatality rate is $1 \%$ or more. ${ }^{14}$ Although this advice was based on inconclusive evidence, now may be the time for national studies into the efficacy of such supplements. On the basis of recent studies the dose of vitamin A should be $400000 \mathrm{IU}$ irrespective of age, rather than the lower doses recommended by the WHO. Supplementation in measles would help to prevent serious complications and death in children until adequate coverage with measles vaccination is achieved in Third World countries and it could be included as part of the routine of primary health care.

Senior Lecturer in Tropical Paediatrics,

Liverpool School of Tropical Medicine,

Liverpool L3 5QA

1 Grant JP. The state of the world's children, 1990. Oxford: Oxford University Press, 1990.

2 Kaschula RO, Druker J, Kipps A. Late morphologic consequences of measles: a lethal and debilitating lung disease among the poor. Rev Infect Dis 1983;5:395-404.

3 Bhaskaram P, Reddy V, Raj S, Bhatnager RC. Effect of measles on the nutritional status of haskaram P, Reddy V, Raj S, Bhatnager RC. Ef
preschool children. f Trop Med Hyg 1984;87:21-5.

4 Foster A, Sommer A. Childhood blindness from corneal ulceration in Africa: causes, prevention, and treatment. Bull WHO 1986;64:619-23. 